\title{
せんだい保育室における既存建物の転用と保育環境の改善に関する研究 A STUDY ON THE CONVERSION OF THE EXISTING BUILDING AND THE IMPROVEMENT OF NURSING ENVIRONMENT IN CERTIFIED DAY-NURSERY IN SENDAI
}

\author{
鈴木 健二*
}

Kenji SUZUKI

\begin{abstract}
The number of children on waiting lists to attend authorized day-care centers is rapidly rising in urban areas, but securing land and the building for the centers is very difficult in those areas. Aiming at the waiting-list child cancellation, the promotion to the non-registered day-care facility that fills an original standard is done in some municipalities. So, the survey was done in Sendai City that was one of such the municipalities.

1) The standard of the SENDAI HOIKU-SHITU nurseries is severer than that of another municipality, but the number of facilities compared with the population is more than that of other municipalities. Moreover, about 70 percent of the whole were the nurseries established from of old.

2) "Small-scale management" and "Use of existing buildings" are the characteristics of SENDAI HOIKU-SHITU nurseries. To fill the area standard, extension and rebuilding to existing buildings were performed in the cases that shifted from KATEI-HOIKU-SHITU nurseries.

3) To deal with the problem of the area standard, in the case where the lease building is used it borrowed the room, and in the case where the ownership building is used rebuilding of home and the use of the vacancy were done.

4) The users with high income seem to be using the SENDAI HOIKU-SHITU nurseries because there is little difference between nursery school fees of the authorization day-care center. However, the users with low income were hoping for the authorization day-care center where the fee is cheaper.
\end{abstract}

Keywords : day nursery, nursing environment, certified day-nursery in Sendai, extention and reconstruction 保育所，保育環境，せんだい保育室，増改築

\section{1.はじめに}

\section{$1-1$. 社会的背景}

少子化の進行により出生数は減少しつつあるが、景気の悪化に伴 う女性の就業増加等を反映して、首都圈や政令指定都市等の都市部 では保育所入所待機児童の数が大幅に増加している。厚生労働省も 2001 年に待機児童ゼロ作戦、2008 年に新待機児童ゼロ作戦を実施 しているが、2010 年 4 月の待機児童数は過去 2 番目に多い 2.6 万人、 また潜在的に保育所入所を希望している児童数は全国で約 80 万人に 達するとされており、保育所の整備が追いつかないのが現状である。

保育所は、児童福祉法に基づき自治体が設置を認可した「認可保育 所」と、児童福祉法上の保育所には該当しない「認可外保育施設」の 2つに分類されるが、認可保育所の整備が都市部で進まない要因の 1 つとして、認可保育所の施設基準がより高く設定されている事が挙 げられている。そこで 2009 年には政府の地方分権改革推進委員会 が認可保育所の基準を「全国一律の規制ではなく、地域の実情に応じ て自治体に委ねる」と勧告したり (第 3 次勧告)、厚生労働省が 2012 年度より全国 35 市区での認可保育所の面積基準緩和を認める（3 年 間限定）等、基準の緩和で保育所の整備を進めようとの動きが見られ る。しかし一方で、1948 年の制定以降 60 年を経過しながら殆ど改 善されていない認可保育所の基準 ${ }^{\text {注 }}{ }^{1)}$ は、諸外国に比べて面積基準が
低く、基準の緩和よりも基準の引上げが必要だとの意見が保育関係 の団体から出される等、保育所の量的整備」という量的な問題と「保 育環境の水準向上」という質的な問題との間で意見が衝突している状 況にある。

このように待機児童の増加に認可保育所の供給が追いつかない一 方で、都市部の一部の自治体では待機児童の問題を少しでも解消し ようと、認可外保育施設であっても独自の基準を満たす施設（以下、 自治体単独保育室 ${ }^{\text {注 } 2)}$ と表記）を認定し、一定の助成を行う事業が 実施されている。1997 年の横浜市を皮切りに、東京都や浜松市など、 自治体単独保育室を導入する自治体は増加しつつある。

\section{1-2. 既往研究の動向}

待機児童の問題が顕在化している現状を反映して、保育所に関す る建築分野の既往研究は増加している。近年では幼保一体型施設注3) 屋外環境 ${ }^{\text {注 }}$ ）、異年齢保育 ${ }^{\text {注 }}$ ）、乳幼児室の適正面積基準 ${ }^{\text {注 }}$ 6) に関す る研究等があるが、これらは全て認可保育所を対象にしたものであ る。これに対して認可外保育施設を対象とした既往研究は非常に少 なく、東京都の自治体単独保育室である「東京都認証保育所」を対象 に含めた小池らの研究注 7 ) が挙げられる程度である。しかし小池ら の研究では東京都の事例という事もあり複合型の事例に焦点が当て られており、自治体単独保育室の全体像を描き出すまでには至ってい 
表 1 主な自治体単独保育室の比較

\begin{tabular}{|c|c|c|c|c|c|c|c|c|c|c|}
\hline & \multirow{2}{*}{ 認可保育所 } & \multicolumn{2}{|c|}{ せんだい保育室（宮城県仙台市） } & \multicolumn{2}{|c|}{ 東京都認証保育所 } & \multirow{2}{*}{$\begin{array}{c}\text { 横浜保育室 } \\
\text { (神奈川県横浜市) }\end{array}$} & \multicolumn{2}{|c|}{ 浜松市認証保育所 (静岡県) } & \multirow{2}{*}{\begin{tabular}{|c|} 
堺市認証保育所 \\
(大阪府)
\end{tabular}} & \multirow{2}{*}{$\begin{array}{l}\text { 認可外 } \\
\text { 保育施設 }\end{array}$} \\
\hline & & $A$ 型 & B型 & $\mathrm{A}$ 型 & B 型 & & I 類 & II 類 & & \\
\hline 立地条件 & $\begin{array}{c}\text { (保育需要が域) } \\
\text { ある地域 }\end{array}$ & \begin{tabular}{|l} 
都市計画法の商業 \\
地域で認可保育所 \\
の設置困難地区
\end{tabular} & - & - & - & - & - & - & - & - \\
\hline 対象児童 & \begin{tabular}{|c|}
$\begin{array}{c}\text { 保育に欠け乳幼児 } \\
\end{array}$ \\
\end{tabular} & $\begin{array}{c}0 \text { 歳〜小学校 } \\
\text { 就学期前 }\end{array}$ & $\begin{array}{c}0 \text { 歳〜小学校 } \\
\text { 就学期前 } \\
\end{array}$ & $\begin{array}{c}0 \text { 歳 小学校 } \\
\text { 就学期前 }\end{array}$ & 0 2 歳 & $0 \sim 2$ 歳 & \begin{tabular}{|c|}
0 歳 小学校 \\
就学期前
\end{tabular} & $\begin{array}{c}0 \text { 歳 小学校 } \\
\text { 就学期前 }\end{array}$ & $0 \sim 2$ 歳 & \\
\hline 施設定員 & \begin{tabular}{|c|}
60 名以上 \\
(小規模保育所 \\
は 20 名以上) \\
\end{tabular} & 45 名以上 & $10 \sim 59$ 名 & $20 \sim 120$ 名 & 6 29名 & 20 名以上 & 20 名以上 & 6名以上 & $20 \sim 45$ 名 & - \\
\hline $\begin{array}{c}\text { 乳幼児 } 1 \text { 人当りの } \\
\text { 面積最低値 } \\
(0 \sim 1 \text { 歳児 }) \\
\end{array}$ & 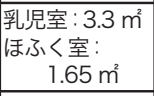 & $3.3 \mathrm{~m}^{2}$ & $2.475 \mathrm{~m}^{2}$ & \begin{tabular}{|c|}
$3.3 \mathrm{~m}^{2}$ \\
$\left(2.5 \mathrm{~m}^{2} ま て ゙\right.$ \\
弾力化 $)$ \\
\end{tabular} & $2.5 \mathrm{~m}^{2}$ & $2.475 \mathrm{~m}^{2}$ & $3.3 \mathrm{~m}^{2}$ & $1.65 \mathrm{~m}^{2}$ & $3.3 \mathrm{~m}^{2}$ & \multirow{2}{*}{$\begin{array}{c}\text { 概权 } \\
1.65 \mathrm{~m}^{2}\end{array}$} \\
\hline $\begin{array}{c}\text { 保育室・遊戯室の } \\
1 \text { 人当り面積最低值 } \\
\text { (2歳罗以上) }\end{array}$ & $1.98 \mathrm{~m}^{2}$ & $1.98 \mathrm{~m}^{2}$ & $1.98 \mathrm{~m}^{2}$ & $1.98 \mathrm{~m}^{2}$ & $1.98 \mathrm{~m}^{2}$ & $1.98 \mathrm{~m}^{2}$ & $1.98 \mathrm{~m}^{2}$ & $1.65 \mathrm{~m}^{2}$ & $1.98 \mathrm{~m}^{2}$ & \\
\hline 保育従事者の資格 & $\begin{array}{l}\text { 全員が } \\
\text { 保育士。 }\end{array}$ & \begin{tabular}{|c|} 
全員が有資格者 \\
(保育士、保健師、 \\
看護師、助産師)。 \\
常勤職員は全体の \\
$2 / 3$ 以上。 \\
\end{tabular} & \begin{tabular}{|c} 
2/3 以上が有資格 \\
者(保育士、保健師、 \\
看護師、助産師)。 \\
常勤職員は全体 \\
の $1 / 3$ 以上。
\end{tabular} & \multicolumn{2}{|c|}{\begin{tabular}{|c} 
正規職員は常勤かつ \\
保育士で、年齢別保育 \\
従事職員定数の \\
6 割以上。
\end{tabular}} & $\begin{array}{l}\text { 2/3 以上は保育士 } \\
\text { 保健師、看讙師、 } \\
\text { 助産師。2/3以上 } \\
\text { の常勤職員で常時 } \\
\text { 複数配置。 }\end{array}$ & \begin{tabular}{|l|}
$1 / 2$ 以上は保 \\
育士、看護師 \\
の有資格者。 \\
正規職員が \\
原則。 \\
\end{tabular} & \begin{tabular}{|c|}
$1 / 3$ 以上は \\
保士育士、 \\
看護師の \\
有資格者。
\end{tabular} & \begin{tabular}{|c|} 
おおむね $1 / 2$ \\
以上は保育士、 \\
看護師、保健師、 \\
幼稚園教諭。 \\
\end{tabular} & $\begin{array}{l}\text { 概ね 1/3 以上は } \\
\text { 保育士、看護師 } \\
\text { の有資格者。常勤 } \\
\text { 職員て常時 } 2 \text { 人 } \\
\text { 以上配置が基本。 }\end{array}$ \\
\hline 開園時間 & 原則 8 時間 & 概ね 13 時間 & 概ね 12 時間 & \multicolumn{2}{|c|}{13 時間以上 } & 基本は 11 時間 & \multicolumn{2}{|c|}{ 原則 11 時間以上 } & 基本は 11 時間 & - \\
\hline 施設数（2011.4） & 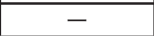 & 5 & 61 & 509 & 89 & 145 & 8 & 17 & 17 & - \\
\hline 制度開始年 & $\begin{array}{lll}- & & \\
\end{array}$ & \multicolumn{2}{|c|}{2002} & \multicolumn{2}{|c|}{2001} & 1997 & \multicolumn{2}{|c|}{2002} & 2004 & - \\
\hline
\end{tabular}

ない。また鈴木が指摘しているように注 8) 、認可保育所の整備に は多額の運営費や補助金が必要となり、政府・自治体の財政的な 制約から新築による認可保育所の大幅な増加は困難である」こと から、既往研究のように対象を認可保育所だけに限定するのでは なく、認可外保育施設をも含めた上で保育環境の水準向上に繋が る具体的な研究が必要だと思われる。

そこで本研究では、自治体単独保育室の中でも基準面積等の引 上げが実際に行われたせんだい保育室を対象に調査を行う。前述 したように 1948 年以降面積基準が殆ど改善されていない認可保 育所の状況を鑑みると、認可外保育施設ではあっても基準面積の 引上げという改善が行われた事実は非常に重要だと考えられる。 せんだい保育室の現状と共に、こうした改善が各園に及ぼした影 響を明らかにする事で、保育環境の水準向上に繋がる知見を得る ことが本研究の目的である。

\section{1-3. 調査方法}

まず始めに自治体単独保育室の動向を整理するために、主な自治体 単独保育室についての基準や基本情報をホームページ等から収集し て整理・分析を行った。また主な調查対象であるせんだい保育室に関 する調査として、仙台市子供未来局保育指導課とせんだい保育室連絡 会へのヒアリング調查、せんだい保育室 8 園の訪問調查を、2009 年 8 月・2010 年 9 月に行った。

\section{2. 自治体単独保育室を対象とした調査結果}

表 1 は主な自治体単独保育室の制度を比較したものである。制度 開始年が 1990 年代後半以降である点、開園時間は全て 11 時間以上 で認可保育所の原則 8 時間よりも長く設定されている点などは共通 しているが、その他の点では自治体によって違いが見られる。東京都・

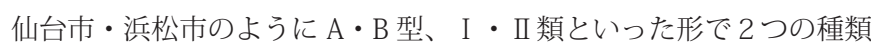
を有している自治体がある一方で、横浜市や堺市のように 1 種類しか ない自治体も見られる。対象児童の年齢についても、低年齢児の「0 〜2歳」のみに限定した自治体と、通常の認可保育所と同様の「0歳 〜小学校就学期前」としている自治体の大きく2つのタイプに分け られる。また施設の定員については、少ないものでは 6 名、多いもの では 120 名となっており、各自治体で大幅に異なっている。

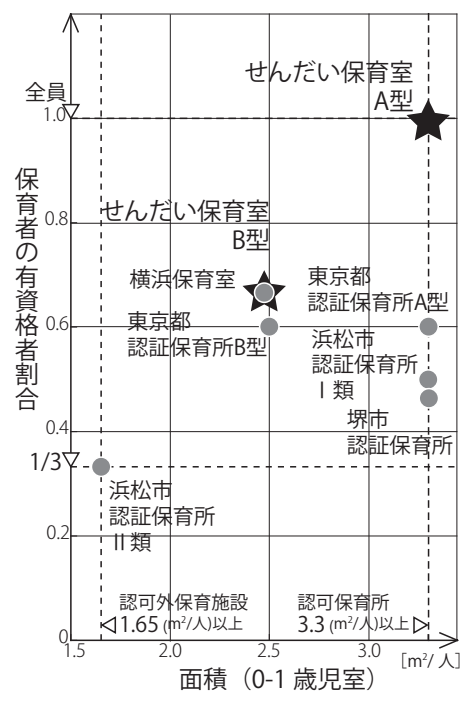

図 1 各自治体の制度の位置づけ

そこで各自治体の制度を比 較するために、ソフト面とし て「保育士の有資格者割合」、 ハード面として「保育室 $(0$ 1 歳) の面積基準」に着目して みる。これらを縦軸・横軸に それぞれ設定し、各自治体単独 保育室の状況をプロットした のが図 1 である。この図では、 右上に行くほど認可保育所の 基準に近くなり、左下に行く ほど認可外保育施設の基準に 近づく事になる。結果として

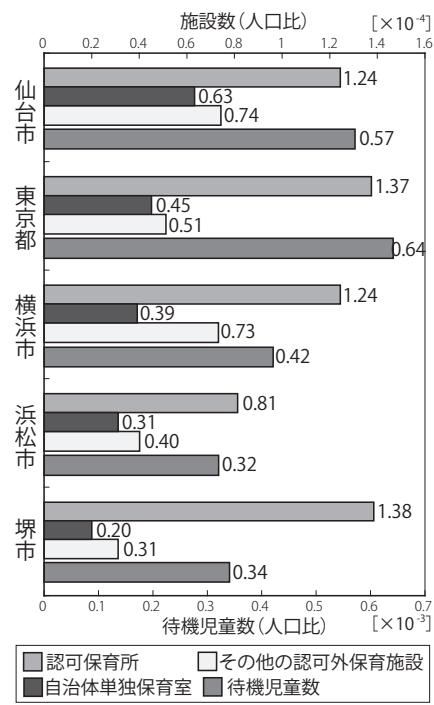
図 2 各自治体の保育所数

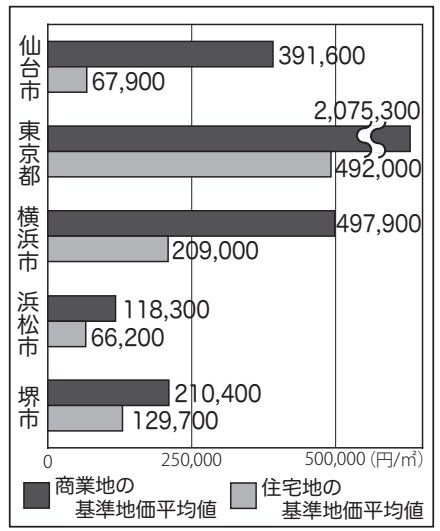

図3 各自治体の商業地と

住宅地の基準地価 (2010 年)

は、全体的に「保育士の有資格者割合」よりも「保育室 $(0 \sim 1$ 歳 $)$ の面積基準」の方が厳しく設定されているが、中でもせんだい保育室 A 型は最も右上に位置しており、認可保育所とほぼ同等の水準である。 またせんだい保育室 B 型は、横浜保育室に非常に近く、保育士の有資 格者の点でも保育室の面積基準の点でも認可保育所と認可外保育施 
設のほぼ中間に位置している事が分かる。

次に各自治体の人口に対する保育施設数と待機児童数を表したの

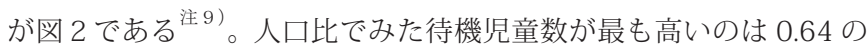
東京都で、仙台市は 0.57、以下横浜市、堺市、浜松市の順となってい る。認可保育所の数值は浜松市が若干低いものの他の 4 自治体は 1.3 前後でさほど差が見られないが、自治体単独保育室と認可外保育施設 の数值は自治体によって差が見られる。中でも自治体単独保育室は、 他の 4 自治体が $0.3 \sim 0.4$ 程度の数值であるのに対し、仙台市では 0.6 を超える数值となっており、制度開始年の違いを考慮に入れても、仙 台市は自治体単独保育室の数が比較的多い自治体だと考えられる。

そして各自治体の商業地と住宅地の基準地価平均值を表したのが 図 3 である ${ }^{\text {注 } 10)}$ 。住宅地・商業地共に東京都の数值が突出して高いが、 どの自治体においても商業地は住宅地よりも $1.6 \sim 5$ 倍程度高い数值 となっており、住宅地と比べると商業地での土地の確保が難しい都市 部での土地事情が窺える。また東京以外の商業地では、横浜市・仙 台市が約 $40 \sim 50$ 万円 / $\mathrm{m}^{2}$ と比較的高い数值となっているが、特に

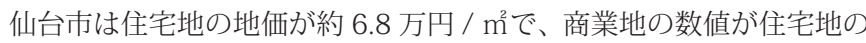
数值の約 5.8 倍と最も大きな差が見られる。

\section{3. せんだい保育室を対象とした調査結果}

\section{3-1. せんだい保育室の概要と家庭保育室}

せんだい保育室は仙台市の保育サービスの質の向上と保育基盤の 整備を目的として 2002 年に開始され、A 型と B 型の 2 種類で実施さ れており（表 2)、2009 年 8 月時点の施設数は A 型が 5 園、B 型が 59 園の計 64 園であった。A 型は、前述したように保育室面積・保 育士等の基準は認可保育所に近く、定員も 45 名以上と規模も比較的 大きい。但し立地については、都市計画法上の商業地域内で認可保育 所の設置が困難な地域との条件がついており、5つの園も JR・地下 鉄双方の駅がある仙台駅・北仙台駅近辺のみに限られていた。これに 対して B 型は面積や保育者の資格の点でも $\mathrm{A}$ 型よりも基準が緩和さ れており、設置地域の制限も特に設けられてはいない。ただし 5 章で 後述するように A 型と B 型とでは保育料に差は無いものの、市から の児童 1 人当り運営費助成単価は $B$ 型が $A$ 型の半分程度という点で

表 2 せんだい保育室と家庭保育室の基準

\begin{tabular}{|c|c|c|c|}
\hline \multirow{2}{*}{ 区分 } & \multicolumn{2}{|c|}{ せんだい保育室 } & \multirow{2}{*}{ 家庭保育室 } \\
\hline & $A$ 型 & B 型 & \\
\hline 設置主体 & $\begin{array}{l}\text { 個人·法人·民間 } \\
\text { 事業者等 }\end{array}$ & 世左に同じ & $\begin{array}{c}\text { 個人.社会福祉法人 } \\
\text { 公益法人 }\end{array}$ \\
\hline $\begin{array}{l}\text { 設置地域 } \\
\text { 条件 }\end{array}$ & \begin{tabular}{|l|} 
都市計画法の商業地域内で \\
認可保育所の設置困難地域
\end{tabular} & 制限なし & 世左に同じ \\
\hline 施設定員 & $\begin{array}{c}45 \text { 名以上 } \\
\text { (3歳未満児を4割以上受入) }\end{array}$ & 10～59名 & 5〜59 名 \\
\hline 保育室採光 & 床面積の 1/7 以上 & 規定なし & 世左に同じ \\
\hline 保育室 0-1 歳 & $3.3 \mathrm{~m}^{2} /$ 人以上 & $2.475 \mathrm{~m}^{2} /$ 人以上 & $1.65 \mathrm{~m}^{2} /$ 人以上 \\
\hline 床面積 2 歳以上 & $1.98 \mathrm{~m}^{2} /$ 人以上 & $1.98 \mathrm{~m}^{2} /$ 人以上 & $1.65 \mathrm{~m}^{2} /$ 人以上 \\
\hline 屋外遊戯場 & $\begin{array}{l}\text { 2歳以上児 } 1 \text { 人当り } 3.3 \mathrm{~m}^{2} \\
\text { 以上。付近の代替場所で可。 }\end{array}$ & 世左に同じ & 付近代替場所で可 \\
\hline 2 階施設 & 児童福禅施設最低基準 & $\begin{array}{l}\text { 指導監督基準 (転落防止設 } \\
\text { 備、非常災害設備の設置等) }\end{array}$ & 世左に同じ \\
\hline 3階以上施設 & 児童福禅施設最低基準 & 世左に同じ & 世左に同じ \\
\hline $\mid \begin{array}{c}\text { 保育従事者の } \\
\text { 資格と常勤 } \\
\text { 職員の割合 }\end{array}$ & $\begin{array}{c}\text { 有資格者: 全員 } \\
\text { (保育士、保健師、 } \\
\text { 看護師、助産師) } \\
\text { 常勤職員 }: 2 / 3 \text { 以上 } \\
\end{array}$ & $\begin{array}{c}\text { 有資格者: } 2 / 3 \text { 以上 } \\
\text { (保育士、保健師、 } \\
\text { 看護師、助産師) } \\
\text { 常勤職員 }: 1 / 3 \text { 以上 } \\
\end{array}$ & $\begin{array}{l}\text { 有資格者：1/3 以上 } \\
\text { (保育士、看護師) } \\
\text { 常勤職員 : 制限なし }\end{array}$ \\
\hline$\left|\begin{array}{c}\text { 児童 } 1 \text { 人当り } \\
\text { の運営費 } \\
\text { 助成単価 }\end{array}\right|$ & \begin{tabular}{|c|} 
(定員 45 60 人の場合) \\
0 歳児 : 118,440 円 \\
$1 \cdot 2$ 歳児 : 54,150 円 \\
3 歳児 : 32,030 円 \\
4歳以上児 : 26,410 円 \\
\end{tabular} & $\begin{array}{r}0 \text { 歳児: } 55,400 \text { 円 } \\
1 \cdot 2 \text { 歳㫛: } 32,900 \text { 円 } \\
3 \text { 歳児: } 16,100 \text { 円 } \\
\text { 4歳以上児: } 13,900 \text { }\end{array}$ & $\begin{array}{r}0 \text { 歲児 : } 30,000 \text { 円 } \\
1 \cdot 2 \text { 歳児: } 30,000 \mathrm{f} \\
3 \text { 歳以上児: } 5,000 \mathrm{f}\end{array}$ \\
\hline
\end{tabular}

大きな違いが見られる（表 2)。

仙台市では 1973 年から一定の基準を満たす認可外保育施設に助 成を行う家庭保育室 ${ }^{\text {注 }}{ }^{11)}$ が実施されており、2000 年には約 50 力所 に達していた（図 4)。しかし、待機児童数が全国的にも上位であっ た仙台市では保育基盤の整備拡充を図るため、「仙台市すこやか子育 てプラン (第 2 期)」の一環として 2002 年から「せんだい保育室」が 新たに創設された。家庭保育室では以前から運営費助成の増額を仙 台市に強く要望していたため、せんだい保育室の創設によって運営 費助成単価の増額が実現された事になるが、それと引き替えに保育 室面積・保育従事者の資格などについての基準もより認可保育所に 近いものへと引き上げられる事になった（表2）注 12）。また従来の家 庭保育室は数年の猶予期間付きで廃止となったため、それまで家庭保 育室であった園が継続して運営を行っていくためには、せんだい保 育室への移行が必要となった。しかし有資格者を新たに雇用したり、 定員を維持したまま基準面積を確保するには保育室の増床が必要と なること等から、せんだい保育室への移行は容易には進まず、2006

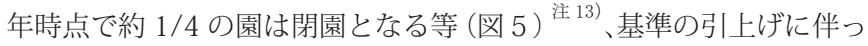
て運営者にとっては厳しい結果も生じている。その後は新しく開設 された園も徐々に現れ、家庭保育室からせんだい保育室へ移行した 園も増えてきたことで、2006 年以降はせんだい保育室の数が家庭保 育室時の数を上回る状況となっている。2006 年時点の構成比率を見 ると（図 6 )、家庭保育室を前身とする園が全体の $67 \%$ を占めており、 せんだい保育室の制度化以前から長期に渡って運営されている園が 多くの割合を占めている事が分かる。

\section{3-2. せんだい保育室の現状}

2009 年 8 月時点のせんだい保育室 64 園の傾向を表 3 ・4 に示す。 まず設置者は、特にB 型で「個人」が多く見られ、全体の約 $70 \%$ を 占めている（表 3)。この要因としては、前述したように家庭保育室 から移行してきた園が多い事によると思われる。次に建物形態につ いては、専用建物の割合は全体の $20 \%$ 未満で、戸建住宅や集合住宅、 ビルの一部を利用しているものが $80 \%$ 以上となっており、既存建物 を改修して開設された事例が大半だと考えられる。東京都認証保育 所を対象とした既往研究では、A 型の $75.5 \%$ が複合型の形態を取つ

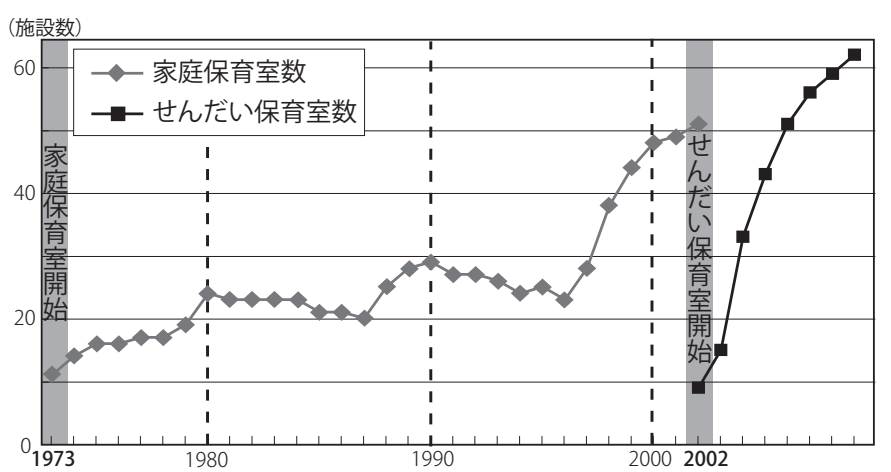

図4 家庭保育室とせんだい保育室の変遷

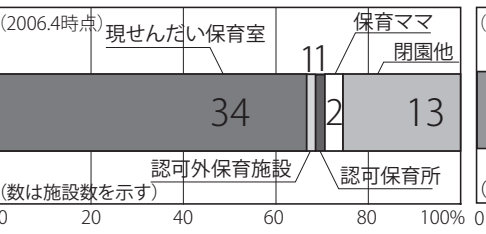

図 5 家庭保育室の移行状況

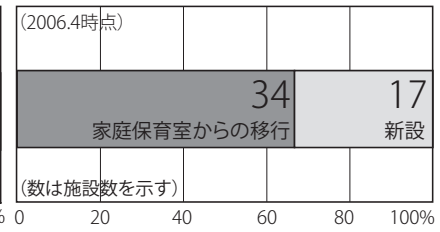

図6 せんだい保育室の構成比 


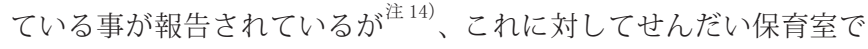
は、集合住宅・業務用ビル・その他を合わせたものを複合型としても その数值は $57.8 \%$ であり、東京都認証保育所 (A 型) と比較すると複 合型の割合がやや少ないこと、そして特に戸建住宅を活用している 園の数が多いことが注目される。また定員は、制度上 A 型が 45 名以 上、B 型が 10 59 名だが、現状は A 型が平均 65.8 名、B 型が 33.4 名、 平均で約 36 名となって伺り (表 4)、認可保育所の平均定員が約 90 名である点を考慮すると、小さな規模で運営がなされていると言え る。そして年齢別在所児童数を仙台市・全国の認可保育所と比較す ると（図 7 )、せんだい保育室では 3 歳未満の児童が全体の半分以上 を占めており、10月に集計を行っている全国の認可保育所との違い を考慮しても、待機児童の約 8 割を占める ${ }^{\text {注 }}{ }^{15)}$ 低年齢の児童をせん だい保育室の方が認可保育所より多く受け入れている事が分かる。

次にせんだい保育室と仙台市認可保育所の立地の状況を示したの が図 8 である ${ }^{\text {注 } 16)}$ 。せんだい保育室（A 型・B 型の合計）では商業地 への立地が全体の約 40\%を占めているのに対して、仙台市認可保育 所では商業地への立地は全体の $15 \%$ 以下と大きな差が見られる。ま た割合だけでなく、実際の施設数についても商業地ではせんだい保 育室が 25 施設で、17 施設の認可保育所を上回っており、図 3 の結 果も考慮すると、地価の高い商業地においては小規模なせんだい保 育室の方が地域の需要に応えている状況にあると考えられる。

最後に各園へのヒアリングから把握した A 型と B 型の状況を以下 に整理する。A 型は設置地域が都市計画法上の商業地域に限定され ており、JR 駅や地下鉄駅等の公共交通機関へアクセスし易い場所に 立地しているため、園の近隣だけでなく通勤途中の保護者も多く利
用しているようだ。施設定員は 45 名以上と B 型よりも規模が大き く設定されているため、当然だが B 型よりも規模の大きい園が多い。 しかし調査時点では専用建物で整備された事例は無く、5事例とも 既存建物の一部を活用したものであった。また園庭については、建 物の屋上に設けられている事例も見られるが、こうした事例では近 隣の公園へ出かける頻度も多いとの事であった。

これに対して B 型は立地条件に制限が無く、前述したように立地 環境は商業地・住宅地など様々だが、今回訪問した園は JR や地下鉄 等の公共交通機関から若干離れた住宅地の立地が多かった。 $\mathrm{A}$ 型と 同様に広い園庭の確保が難しい事から近隣の公園を遊び場としてい る園が多く、大きな公園に近い事を開設場所選定の理由に挙げる園 も見られた。またこうした住宅地では園児の声や音に加えて、保護 者による車での送迎が苦情の原因となりかねないため、近隣に迷惑 が掛からないよう十分な注意を払っているとの意見が多く聞かれた。

\section{4. せんだい保育室 : 個別の事例調査の結果}

\section{4-1. 調査事例の概要}

訪問調查を行ったのは、表 5 に示す 8 園（A 型： 3 園、B 型： 5 園） である。園の選定に際しては、立地場所や建物形態に大きな偏りがな く、既存建物の増改築に着目するため事業開始年が古いものを多く 含めるよう留意した。A 型でも繁華街の仙台駅近辺に立地する $\mathrm{ME}$ 園と AS 園では、保育所が 5 階・6 階と建物の最上階に設置されてい るが、その他の園では 1 階又は $1 \cdot 2$ 階の低層階に設けられている。

\section{4-1-1.ME 園}

今回の事例の中では
表 4 平均定員の比較

\begin{tabular}{|c|c|c|c|}
\hline \multicolumn{2}{|c|}{ せんだい保育室 } & \multirow{2}{*|}{ 仙台市 } & 全国 \\
\cline { 1 - 2 } A 型 & B 型 & 認可保育所 & 認可保育所 \\
\cline { 1 - 2 } 65.8 名 & 33.4 名 & \multirow{2}{*}{91.2 名 } & \multirow{2}{*}{92.2 名 } \\
\hline \multicolumn{2}{|c|}{35.9 名 } & & \\
\hline
\end{tabular}

せんだい保育室と仙台市認可保育所は 2009 年、全国認可保育所は 2008 年のデー夕

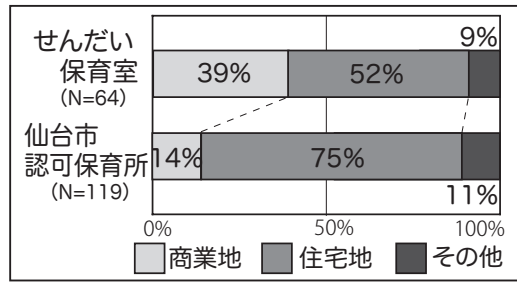

図8 保育所の立地状況（2009 年）

表 5 調查事例の概要

\begin{tabular}{|c|c|c|c|c|c|c|c|c|}
\hline 施設名 & ME 園（A 型） & AS 園（A 型） & MK 園 (A 型) & PS 園（B 型） & CR 園（B 型） & CB 園（B 型） & SI 園（B 型） & MM 園（B 型） \\
\hline & & & & & & & & \\
\hline 所在地 & 仙台市青葉区 & 仙台市青葉区 & 仙台市青葉区 & 仙台市泉区 & 仙台市青葉区 & 仙台市青葉区 & 仙台市青葉区 & 仙台市泉区 \\
\hline 用途地域 & 商業地域 & 商業地域 & 商業地域 & 第二種住居地域 & $\begin{array}{c}\text { 第一種低層住居 } \\
\text { 専用地域 }\end{array}$ & 第二種住居地域 & $\begin{array}{l}\text { 第二種中高層 } \\
\text { 住居専用地域 }\end{array}$ & $\begin{array}{c}\text { 第一種低層住居 } \\
\text { 専用地域 }\end{array}$ \\
\hline 事業開始年 & 2002 年 & 1987 年 & 1992 年 & 1997 年 & 1978 年 & 1985 年 & 1986 年 & 1982 年 \\
\hline \begin{tabular}{|c|} 
せんだい \\
保育室認定年 \\
\end{tabular} & 2002 年 & 2003 年 & 2004 年 & 2004 年 & 2005 年 & 2003 年 & 2003 年 & 2003 年 \\
\hline 入所定員 & 52 名 & 60 名 & 97 名 & 35名 & 25 名 & 20 名 & 34名 & 53 名 \\
\hline 運営主体 & 株式会社 & NPO 法人 & 個人 & 個人 & 個人 & 個人 & 個人 & 個人 \\
\hline 建物概要 & 6 階建・駅ビル & 5 階建·雑居ビル & 10 階建·集合住宅 & 2階建·集合住宅 & 2階建·戸建住宅 & 2階建·戸建住宅 & 2階建·戸建住宅 & 2 階建·戸建住宅 \\
\hline 保育所設置階 & 6 階 & 5 階 & 1 階 & $1 \cdot 2$ 階 & 1·2階 & 1 階 & 1 階 & 1 階 \\
\hline 保育所床面積 & $207 \mathrm{~m}^{2}$ & $258 \mathrm{~m}^{2}$ & $423 \mathrm{~m}^{2}$ & $136 \mathrm{~m}^{2}$ & $118 \mathrm{~m}^{2}$ & $69 \mathrm{~m}^{2}$ & $191 \mathrm{~m}^{2}$ & $171 \mathrm{~m}^{2}$ \\
\hline 所有形態 & 賃貸建物 & 賃貸建物 & 賃貸建物 & 賃貸建物 & 賃貸建物 & 日己所有建物 & 自己所有建物 & 目己所有建物 \\
\hline
\end{tabular}


唯一、せんだい保育室の制度化に合わせて 2002 年から事業を開始 した園である。以前は事務所が入っていた場所を転用して 6 階建・ 駅ビルの最上階に開設されており、通勤途中の保護者の利用にも非 常に便利な場所に立地している。保育所としては比較的上部の階に 設けられているが、駅ビルの広大な屋上にペントハウスのような形 で設置されており、すぐ横には約 300 台収容の大型駐車場（駅舎の 屋上に設置）が面する等、採光・通風等の条件は比較的良好である。 また他の園とは異なり、保育室に接するように大きな園庭も駅舎の 上に確保されている。

\section{4-1-2.AS 園}

1987 年に仙台駅前の朝市内の 5 階建・雑居ビルの最上階で事業を 開始し、2003 年にせんだい保育室に移行した園である。朝市の商店 街振興組合の協力を得ながら運営が行われており、散歩等の外出時 には朝市の店員からも良く声が掛けられている。ME 園と同様、仙台 駅前に立地しており、通勤途中の保護者の利用にも非常に便利な場 所である。商業地域内だが最上階という事もあり、採光・通風等の 条件は概ね良好である。屋上に園庭が設けられているが、実際には 近隣の寺院や公園等に頻繁に出かけているとの事である。せんだい 保育室移行時には面積の不足は無かったが、保育室が 5 階に設置さ れているため、避難階段の増設や内装の張替えが行われている。

\section{4-1-3.MK 園}

1992 年に 10 階建・集合住宅の 1 階で事業を開始し、2004 年に せんだい保育室に移行した園である。定員は 97 名とせんだい保育 室の中でも規模は大きいが、JR と地下鉄が乗り合わせる駅の近辺に あるため通勤途中の保護者の利用も多く、全体の約 $2 / 3$ は近隣以外 からの利用との事であった。10 階建ての建物の屋上にも園庭が設 けられているが、実際には近隣の公園に出かける事が多いようであ る。当初は 1 階の 1 区画だけで運営していたが、2004 年のせんだい 保育室移行時に面積が不足したため、廊下を挟んだ区画を借り足し、 現在は 2 区画で運営が行われている。2 区画で運営されているため、 保育室同士が見えない事や職員同士の連携という点では問題もある が、低年齢児と高年齢児の生活リズムを保持できるという点ではメ リットもあるとの意見も職員から聞くことが出来た。

\section{4-1-4.PS 園}

1997 年に 3 階建・集合住宅で事業を開始し、その後せんだい保育 室に移行した園である。地下鉄の終着駅に近く、近隣には大規模な 都市公園が広がっているため、この場所を選定したとの事である。 当初は 1 階だけの運営だったが、0 歳児保育開始時とせんだい保育 室移行時に面積が不足して、2 階の単身用住戸を 1 部屋ずつ計 2 部 屋借り足しており、現在は 1 ・2 階を跨いだ運営となっている。保育

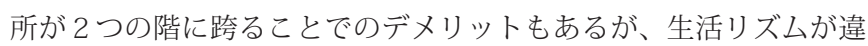
う低年齢児と高年齢児とを分けることができるため、メリットの側 面もあるとの意見が職員から聞かれた。また事務所や単身用住戸だっ た部屋を利用しているため収納場所が少ないのが難点で、単身用住 戸のユニットバスが主要な収納場所として利用されている。

\section{4-1-5.CR 園}

1982 年に事業を開始後、2005 年にせんだい保育室に移行し、現 在は 2 階建・戸建住宅を利用して運営している園である。公共交通の 駅からやや離れた住宅地に立地しており、通園手段は車での送迎が 多いとの事である。以前は保育室が 1 階の夕、定員も約 15 名と小規
模な運営だったが、せんだい保育室への移行時に面積不足の解消と 定員増加を目的とした建物の増築 (約 $\left.10 \mathrm{~m}^{2}\right)$ ・改修が行われている。 せんだい保育室への移行は 2005 年であるが、資格を持った職員が 少なく、増改築の資金調達も困難だったため、移行までに準備期間が 必要だったとの事である。建物は戸建住宅だが現在は住宅として使 用している部屋は無く、1 階・2 階共に保育所として利用されている。

\section{4-7-6.CB 園}

1985 年に自宅の 2 階建・戸建住宅の 1 階部分を利用して事業を開始 し、2003 年にせんだい保育室に移行した園である。公共交通の駅か らはやや離れた住宅地に立地しており、通園手段は車での送迎が多 いとの事である。2003 年のせんだい保育室移行時に面積が不足した ため、増築はしていないが 1 階部分を一部改修している。2 階は運 営者の自宅、1 階を保育所として利用している。定員が 20 名と小規 模な運営ということもあり、対象を 3 歳以下の児童に限定しており、 4 ・ 5 歳児は基本的に認可保育所や幼稚園に移ってもらっていると の事であった。

\section{4-1-7.SI 園}

1986 年に自宅の 2 階建・戸建住宅を利用して事業を開始し、2003 年にせんだい保育室に移行した園である。公共交通の駅からはやや 離れた住宅地に位置しており、通園手段は車での送迎が多いとの事 である。当初は自宅だけで運営していたが、2003 年のせんだい保育 室移行時に面積が不足したため、空家だった隣接住宅を取得すると 共に、庭に増築（約 $100 \mathrm{~m}^{2}$ ）をして 2 軒の住宅を一体化している。 2 階は運営者の自宅や倉庫として使用されており、保育所として利 用しているのは 1 階部分のみである。

\section{4-7-8.MM 園}

1982 年に自宅の 2 階建・戸建住宅を利用して事業を開始し、その 後せんだい保育室に移行した園である。公共交通の駅からは離れた 郊外住宅地に立地しており、通園手段は殆どが車での送迎との事で ある。SI園と同様に当初は自宅だけで運営していたが、2003 年の せんだい保育室移行時に面積が不足したため、空家となった隣接住 宅を取得し、増築（約 $10 \mathrm{~m}^{2} ）$ により一体化がなされている。その後、 隣接する空家を更に 1 軒取得し、現在では 3 軒の戸建住宅を利用し て、2 階は自宅や倉庫等、1 階は保育所として運営されている。保 育所が 3 つ建物に分かれることでデメリットもあるが、生活リズ ムが違う低年齢児と高年齢児とを分けられること、インフルエンザ などの感染症への対応が取りやすいこと等、メリットの側面もある との意見が職員から聞かれた。

\section{4-2. 8園の「増床の有無」と「建物の所有形態」}

これら 8 園の内、せんだ い保育室の制度化以前から 運営されていたのは ME 園 を除く 7 園だが、これらを 「増床の有無」と「建物の所 有形態」とで分類したのが 図 9 である。前述したよう に、従前の定員を減らさず にせんだい保育室の基準面 積を確保するには増床が必 要となったが、保育室の面

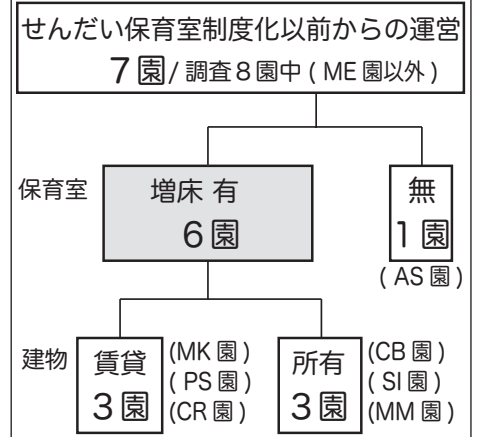

図 9 増床の有無と所有形態 
積に余裕があった AS 園を除いて ${ }^{\text {注 17) }}$ 、他の 6 園では何らかの方法で 園の増床が行われていた ${ }^{18)}$ 。こうした増床を行うには建物が自己 所有か賃貸かで大きく対応が異なるが、これら 6 園の内、賃貸建物 が 3 園、自己所有建物が 3 園ずつであった。以下では賃貸建物と自 己所有建物とに分けてそれぞれ見ていく。

\section{4-3. 賃貸建物での増床事例}

増床を行った 6 園の内、賃貸建物を利用している事例は MK 園・ PS 園・CR 園だが、MK 園・PS 園の 2 園では新たに部屋を借りる事 で増床が行われていた。10 階建て集合住宅の 1 階部分を利用してい る MK 園では、せんだい保育室移行時に保育室の面積が不足したた め、共用通路を挟んだ同じ 1 階に 1 部屋借り足す事で増床がなされ ている(図 10)。従来使用していた場所は 0 ～2 歳児用の保育室と して、新たに借りた場所は $3 \sim 5$ 歳児用の保育室としてそれぞれ使 用されている。一方 3 階建て集合住宅の 1 階部分を利用している PS 園では、0 歳児保育開始時 (2001 年) とせんだい保育室認定時 (2004 年）に 2 階の住戸を一部屋ずつ計 2 室を借り足して保育室の面積を 満たしている。2 階の 2 室はそれぞれ $0 \cdot 1$ 歳児の保育室として利用 されているが、賃貸物件のため改修は殆どなされていない。

こうした増床の結果、MK 園では平面的に、PS 園では上下階に保 育室が分離しており、互いの保育室が見えないため、ヒアリングで は職員間での連携や配膳時などに不便を感じているとの事であった。 また $\mathrm{A}$ 型の $\mathrm{MK}$ 園は年齢別保育としてクラス毎に保育士が固定配置 されているが、分離した保育室同士では保育士の移動ができないた め、園児数の変動への対応が難しく、運営面での負担も生じている ようだ。しかしその一方で、0２歳児と $3 〜 5$ 歳児はある程度独 立させた方が園児が落ち着いて生活できるとの職員の意見もあり、
保育室の分離によるメリットの側面も見られるようだ。

このように MK 園・PS 園では賃貸建物のため、大幅な増改築では なく、利用する部屋を新たに借りる事で必要な保育室面積を確保し ていたが、CR 園ではせんだい保育室への移行時に建物への増改築が 行われていた。これは建物所有者が保育園の運営に大きな理解を示 しており、改修後の原状復帰を求めていないため、後述する所有建 物と同様に建物の増改築が行われたものと考えられる。

\section{4-4. 自己所有建物での増床事例}

自己所有の建物を利用して増床が行われたのが SI 園・MM 園・CB 園である。CB 園・SI 園・MM 園共に、運営者の自宅を家庭保育室と して利用していたが、せんだい保育室認定に際して保育室面積の拡 大が必要となった点では共通している。ここでは所有建物と同様に 増改築がなされた CR 園も含めた 4 事例を対象に考察を行う。

4 事例とも家庭保育室から移行した園であり、せんだい保育室の 認定を受ける際には面積拡張のために建物の増改築がなされている。 増改築の資金は自己負担もしくは赤い羽根共同募金によるものが大 半で、自治体からの助成は全くなされていないとの事であった。こ れらの 4 事例が行った増改築の方法を「敷地内の増築余地の有無」「隣 接地の活用の有無」という観点で分類すると、既存建物の改修のみ の事例、既存建物の改修に加えて敷地内で増築を行った事例、敷地 内だけでなく隣地の空家を含めて一体的に増改築を行った事例、と いう３つの方法に大きく分類する事ができる（図 11）。尚、この 4 事例では $\mathrm{a}<\mathrm{b}<\mathrm{c}$ の順に入所定員が大きい結果となった。

\section{4-4-1. 既存建物の改修による面積拡張}

敷地内に増築の余地が無く、隣接地の取得も困難だったため、既 存建物の改修のみで面積拡張が図られたケースである (図 11-a)。CB

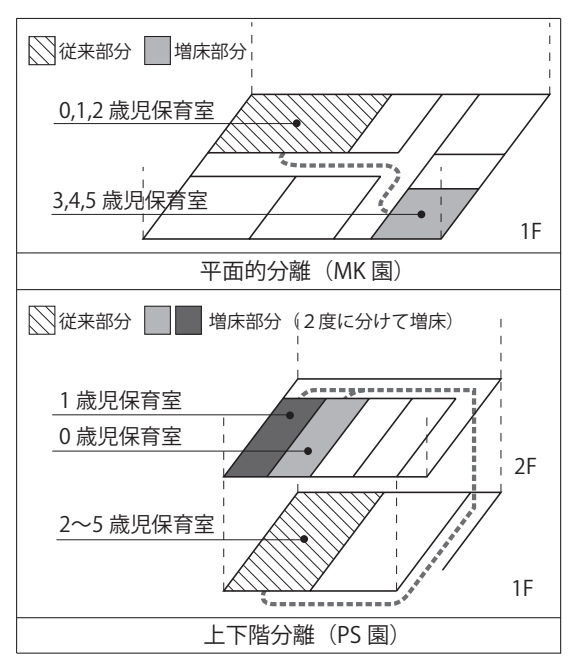

図 10 保育室の分離の形態

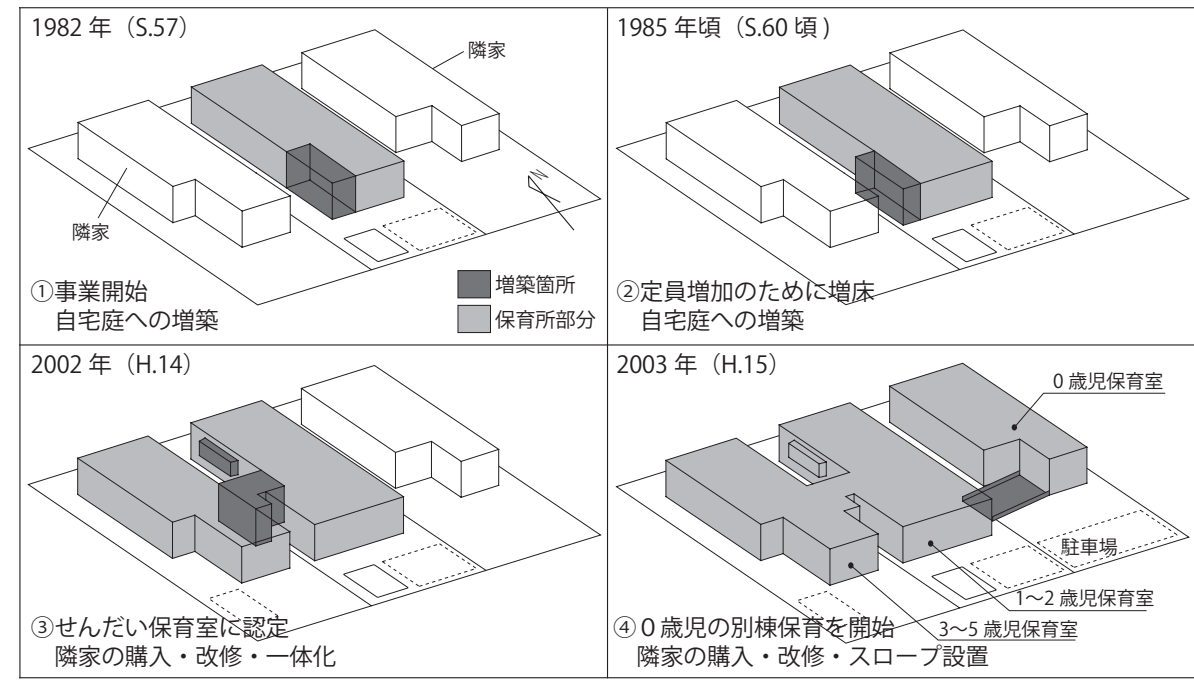

図 $13 \mathrm{MM}$ 保育室の改修過程（1 階部分のみ記載）

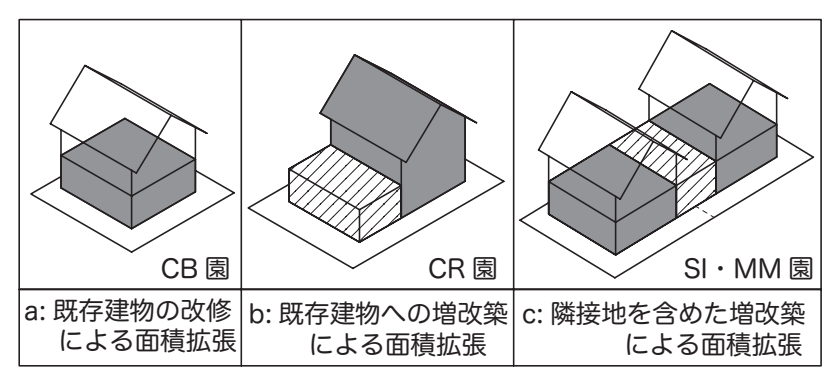

邓增築箇所 $\square$ 保育所使用部分

図 11 既存建物の増改築による面積拡張の方法

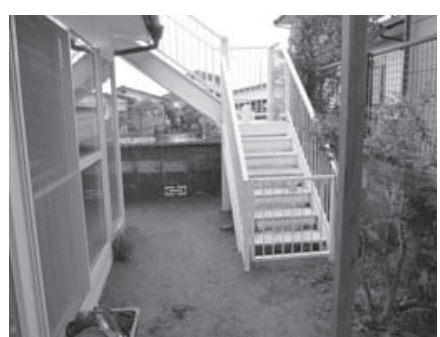

図 12 庭に新設された 避難階段 (CR 園)

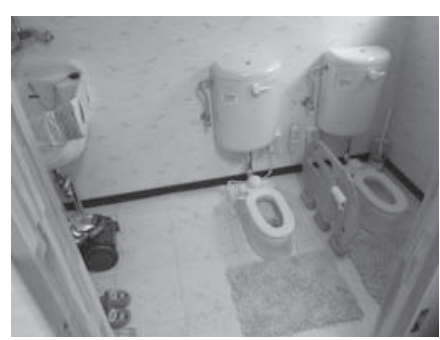

図 14 浴室を改装した 幼児用トイレ (MM 園) 
園では敷地が狭いために建物を増築する余地が殆ど無く、市中心部 に近い事から隣接地の取得も困難であった。また建物の 2 階は運営 者家族が自宅として使用するために、保育所として利用できる場所 は既存建物の 1 階部分のみに限られていた。そこで玄関の位置を変 えたり、押入を取払って保育室の一部とする等の対応を行うと共に、 定員も20 名と小規模に抑える事で基準面積が確保されている ${ }^{\text {注 }}$ 。 押入などの場所も保育室に改修しているため、物品の収納場所の確 保が困難となっており、移動式の家具を使用したり、物品を壁面に 掛けたりする等の工夫が行われている。

\section{4-4-2. 既存建物への増改築による面積拡張}

隣接地への拡張は困難だが敷地内に増築の余地があったため、既 存建物への増改築により面積の拡張が図られたケースである（図 11-b)。CR 園は敷地面積がやや広く、敷地内に増築の余地があった ため、基準面積の確保と定員の増加を目的として約 $10 \mathrm{~m}$ の増築が 行われた。当初は保育室を 1 階のみに設けていたため定員も 20 名と 少なかったが、その後改修費用の予算が確保できたことから保育室 を2 階にも設置し、定員も 25 名へと増加させている ${ }^{\text {注 } 20)}$ 。尚、保育 室の 2 階への設置に際しては新たに屋外避難階段が設けられており、 既存建物を転用して保育所を 2 階以上に設置する場合は、こうした 避難時への対応も必要となる（図 12）。

\section{4-4-3. 隣接地を含めた一体的な増改築による面積拡張}

空家となった隣接地の建物・土地を取得し、敷地内だけでなく複 数の敷地に跨って建物の増改築を行う事で面積の拡張が図られた ケースである (図 11-C)。SI 園・MM 園はどちらも運営者の自宅を利 用して家庭保育室として始まったが、せんだい保育室への移行時に SI 園では南側隣接地の建物を加えた計 2 棟を、MM 園では両隣の建 物を加えた計 3 棟をそれぞれ増改築し、一体化した運営がなされて いる。CB 園と同様に、SI 園・MM 園共に 2 階は一部が運営者の居住 スペースとして利用されており、保育室は 1 階部分の夕が用いられ ている。しかし複数の建物を繋ぎ合わせているために 1 階部分の面 積は比較的広く、定員も 34 人 $\cdot 53$ 人と比較的多く設定されている。 また収納場所が少なくて苦労する園が多い中で、SI 園・MM 園では 居住スペース以外の 2 階を物置として使用する等、他の転用事例と 比較しても収納場所が十分に確保されていた。

特に MM 園では 4 段階の増改築が行われている (図 13)。家庭保 育室として事業を開始した 1982 年に 1 度目の増築が行われ、その 数年後にも園児数の増加に伴って庭に更に増築を実施。そして 2002 年には、空家になった隣家を購入・改修すると共に、元の建物と一 体化してせんだい保育室への移行を実現。更にその翌年には東側の 隣家も購入・改修し、0 歳児用のベビー館として開設している（こ ちらは既存建物との一体化は行われていない)。また建物の前面には 送迎用として数台分の駐車場が設けられているが、送迎時以外は使 用しないため、夜間や帰省時などの駐車場が十分に確保できない近 隣の住民に対して駐車場を開放する等、空家となった建物と同様に 有効活用が行われている。

\section{4-5. 既存建物への増改築時の問題点}

ただし、こうした既存建物への増改築手法が他の事例でも何の問 題もなく適用できるという訳ではなく、注意すべき点も幾つか考え られる。まず 1 点目は建蔽率・容積率の確認である。今回の調査事 例では建蔽率・容積率に比較的余裕がある事例だったこともあり問
題は無かったようだが、特に住居系の用途地域では建蔽率・容積率 の制限が厳しい事もあるため、事前の確認が必要となるだろう。

そして 2 点目は既存建物への遡及適用の問題である。2005 年 6 月 施行の建築基準法等改正に伴い、「既存不適格建築物に関する規制の 合理化」の措置の 1 つとして「構造耐力規定の適用の合理化」が講じ られた。同改正によって、構造耐力規定を遡及適用させる増築面積 の基準として「従前の延べ面積の $1 / 2 」 「$ 増築又は改築に係る部分の 床面積の合計が基準時における延べ面積の $1 / 20$ (50 m²超える場 合は、 $\left.50 \mathrm{~m}^{2}\right) 」$ が明確に示された事で、これを超える規模の増築では 構造耐力規定が遡及適用される事になる。せんだい保育室の制度化 は 2005 年の建築基準法改正より 3 年早い 2002 年の実施で、今回 訪問調查を行った事例も全て 2005 年 6 月以前に増改築が行われて いるため同改正の対象外ではあるが、参考として増築の規模につい て見てみる。増築が行われた 3 園では増改築費用が自己負担又は共 同募金の助成だった事もあり、MM 園・CR 園の増築面積は $10 \mathrm{~m}^{2}$ 程 度と小規模で、規模が最も大きかった SI 園でも増築面積は約 $100 \mathrm{~m}^{2}$ であった。したがって「従前の延べ面積の 1/2」を超える大規模な増 築では無く、対象であったとしても既存建物には遡及適用されなかっ たと思われる。しかし、増築面積の規模次第では既存建物への遡及 適用が問題となるケースが生じてくるため、こうした遡及適用の可能 性についても今後は検討する必要があると考えられる。

\section{4-6. 既存建物から保育所への転用時の問題点}

次に建物の増改築時に限らない、保育所への転用時に生じる共通の 問題点を 2 点指摘する。まず 1 つ目がトイレの整備である。認可外保 育施設指導監督基準により、定員が 20 人を超える園では複数のトイ レが必要となるため、定員次第では従前の建物をそのまま活用できる 訳ではない。今回の事例でも特に戸建住宅を活用した事例では、従前 の建物にトイレが 1 箇所しかないものが殆どで、CR 園では増築に併 せて新たにトイレが設置されていた。また SI 園・MM 園では 2 棟の 戸建住宅を一体化して複数のトイレが確保できたため、すぐには問題 とならなかったが、その後不要となった浴室を幼児用トイレに改修す る等の対応がなされている（図 14）。

そして2つ目が送迎用駐車場の確保である。公共交通の利便性が 高い場所や大都市圈ではさほど必要ないかもしれないが、特に B 型 の 6 事例は駅からやや離れた住宅地に立地しているため、自家用車 による送迎が非常に多いとの事であった。そこで、路上駐車などに より近隣住民からの苦情が生じないようにするために、どの園でも 送迎用の駐車場が数台分確保されていた。ただし今回訪問調査を行っ た事例では、園の敷地内に駐車場を確保できていたのは、戸建住宅 3 棟分を一体的に利用している MM 園の 1 園のみで、他の大半の事 例では道路向かいの場所や徒歩数分の場所など、園の敷地外で駐車 場を確保せざるをえない状況であった。

\section{5. 運営面についての課題とせんだい保育室連絡会の活動}

最後に運営面についてである。せんだい保育室のような自治体単 独保育室と認可保育所との大きな違いとして、まず保育料の問題が 挙げられる。せんだい保育室と仙台市認可保育所の保育料徵収額の 一覧を表 6 に示す。認可保育所は所得税額や市町村民税の課税状況 に応じて保育料が決まるが、せんだい保育室の保育料は所得とは関 係無く子供の年齢で一律に決定されるため（A 型・B 型共に保育料 
は同額である)、所得が比較的高い階層区分 D8 D10 の利用者に とっては、認可保育所の保育料と殆ど差がない。したがってこうし た利用者の中には保育料の違いよりも利便性・保育方針・環境等の 観点から認可保育所ではなくせんだい保育室を自ら選択して利用す るケースも見られるようだ。その一方で、母子家庭などで所得が低く、 認可保育所への入園が困難なために一時的にせんだい保育室を利用 しているケースも多いとの事である。こうしたケースでは利用して いるせんだい保育室を気に入っていても、保育料の安い認可保育所 に空きが出ると保育料の差が大きいためにせんだい保育室から移っ てしまう状況にある等、保育料の違いは利用者・運営者双方にとっ ての課題となっているようだ。

こうした課題を解決するための活動を継続的に行っているのが「せ んだい保育室連絡会」である。「せんだい保育室連絡会」は、家庭保 育室の園長有志により 1999 年に発足した「家庭保育室連絡会」を 前身としており、せんだい保育室に移行後も保育の質の向上を目的 とした勉強会や市との懇談会を中心に活動が行われている 注21)。そ の中で市長や保育課との意見交換や署名活動、要望書の提出といっ た活動が継続的に行われた結果、これまでに有資格者雇用への補助 (2003 年) や多子減免制度 (2007 年)、保育料の保護者負担軽減制 度 $^{22)}$ (2010 年) 等、主に運営面での改善が数多く実現されている(表 7)。特に保育料の多子減免制度や、保育料の保護者負担軽減制度に ついては、せんだい保育室の運営者側よりも利用者側が受けるメリッ トが大きいものであり、こうした改善が「せんだい保育室連絡会」の 活動を通して実現されている点は注目すべき点だと思われる。

\section{6. まとめ}

本研究では、自治体単独保育室の中でも、基準面積の引上げ等、 保育環境の改善が行われたせんだい保育室を対象に調査を実施し、 せんだい保育室の現状と、こうした変化が各園に及ぼした影響など について考察し、以下の知見を得た。

1 ) 独自の基準を満たす認可外保育施設に助成を行う自治体単独保 育室が幾つかの自治体で導入されているが、対象児童の年齢や保育 室の面積基準については各自治体によって差が見られ、特にせんだ い保育室の基準はハード・ソフト共にやや厳しく設定されていた。 また仙台市では一定の基準を満たす認可外保育施設に助成を行う家 庭保育室が 1973 年から実施されていたが、この家庭保育室を前身 とする開設期間の長い園がせんだい保育室へ移行したこともあり、 人口比でみた施設数は他自治体よりも多い。

2 ）せんだい保育室の特徵としては、定員が平均約 36 名という認可 保育所と比較すると小規模な運営と、8 割以上が既存建物を改修し て運営されているという既存建物の活用の 2 点が挙げられる。せん だい保育室への移行時には前身の家庭保育室よりも保育室の面積基 準が引上げられたため、定員を減らさずに基準面積を確保するには 保育室面積の増加が必要となり、一部の園では閉園を余儀なくされ た。しかし約 $2 / 3$ の園では既存建物への増床や増改築を行うことで 基準面積を満たし、せんだい保育室への移行を実現させていた。

3 ）既存建物の増床方法は、建物が賃貸建物か自己所有建物かによっ て対応が大きく異なっていた。賃貸建物を利用した事例では原状復 帰が求められるため大がかりな工事は困難で、基本的には部屋を新 たに借りる事で増床が行われており、複数の保育室が同一階で平面
表 6 認可保育所 (上表) とせんだい保育室 (下表) の保育料徴収基準額

\begin{tabular}{|c|c|c|c|c|c|c|c|c|}
\hline & \multirow{3}{*}{\multicolumn{2}{|c|}{\begin{tabular}{|l} 
階層認定の基準 \\
(父母及び同一生計世帯の主宰 \\
者である扶養義務者の合計額) \\
\end{tabular}}} & \multicolumn{6}{|c|}{ 認可保育所（仙台市，月額） } \\
\hline \multirow{2}{*}{\begin{tabular}{|l|} 
階層 \\
分 \\
\end{tabular}} & & & 3 歳未 & 末満児 & 3歳 & & 4歳以 & 上児 \\
\hline & & & 基準額 & 第2子 & 基準額 & 第2子 & 基準額 & 第2子 \\
\hline A & \multicolumn{2}{|c|}{$\begin{array}{l}\text { 生活保護世帯及び中国残留邦人 } \\
\text { 等の円滑な帰国の促進及び永住 } \\
\text { 帰国後の自立の支援に関する法 } \\
\text { 律による支援給付受給世帯 }\end{array}$} & $\begin{array}{l}\text { 円 } \\
0\end{array}$ & $\begin{array}{l}\text { 円 } \\
0\end{array}$ & $\begin{array}{l}\text { 円 } \\
0\end{array}$ & $\begin{array}{l}円 \\
0\end{array}$ & $\begin{array}{l}\text { 円 } \\
0\end{array}$ & $\begin{array}{l}\text { 円 } \\
0\end{array}$ \\
\hline B & \multicolumn{2}{|c|}{\begin{tabular}{|l|} 
A階層及びD階層を除き20年度分 \\
市町村民税課課税世帯
\end{tabular}} & 0 & 0 & 0 & 0 & 0 & 0 \\
\hline \multirow{2}{*}{ C1 } & \multirow{4}{*}{\begin{tabular}{|l|} 
A 階層及びD階 \\
層を除き 20 年度 \\
分市町村民税が \\
次の区分の世帯 \\
\end{tabular}} & \multirow{2}{*}{ 均等割課税 } & 7,650 & 2,290 & 5,200 & 1,560 & 5,200 & 1,560 \\
\hline & & & 6,650 & 1,990 & 4,200 & 1,260 & 4,200 & 1,260 \\
\hline \multirow[b]{2}{*}{ C2 } & & \multirow{2}{*}{ 所得割課税 } & 8,860 & 2,650 & 6,300 & 1,890 & 6,300 & 1,890 \\
\hline & & & 7,860 & 2,350 & 5,300 & 1,590 & 5,300 & 1,590 \\
\hline D1 & \multirow{7}{*}{$\begin{array}{l}\text { A階層を除き20 } \\
\text { 年度分の所得税 } \\
\text { 課税世帯であっ } \\
\text { て,その所得税 } \\
\text { の額が次の額で } \\
\text { ある世帯 }\end{array}$} & 6,000円未満 & 11,700 & 3,970 & 9,200 & 3,120 & 9,200 & 3,120 \\
\hline D2 & & \begin{tabular}{|l|}
6,000 円以上 \\
16,000 円未満
\end{tabular} & 15,300 & 5,810 & 12,700 & 4,820 & 12,700 & 4,820 \\
\hline D3 & & $\begin{array}{l}16,000 \text { 円以上 } \\
28,000 \text { 円満 }\end{array}$ & 20,700 & 8,690 & 17,500 & 7,350 & 17,500 & 7,350 \\
\hline D4 & & \begin{tabular}{l|} 
28,000円以上 \\
40,000円未満
\end{tabular} & 27,400 & 12,600 & 21,800 & 10,020 & 21,800 & 10,020 \\
\hline D5 & & \begin{tabular}{l|} 
40,000円以上 \\
56,000円未満
\end{tabular} & 33,500 & 16,750 & 24,300 & 12,150 & 24,300 & 12,150 \\
\hline D6 & & \begin{tabular}{l|} 
56,000円以上 \\
72,000円未満
\end{tabular} & 39,000 & 19,500 & 25,300 & 12,650 & 24,900 & 12,450 \\
\hline D7 & & \begin{tabular}{|r|} 
72,000円以上 \\
103,000円未満 \\
\end{tabular} & 44,500 & 22,250 & 26,100 & 13,050 & 25,500 & 12,750 \\
\hline D8 & & \begin{tabular}{|l|} 
103,000円以上 \\
235,000円未満 \\
\end{tabular} & 49,900 & 24,950 & 26,900 & 13,450 & 26,600 & 13,300 \\
\hline 9 & & \begin{tabular}{|l|} 
235,000円以上 \\
413,000円未満
\end{tabular} & 53,500 & 26,750 & 27,700 & 13,850 & 27,200 & 13,600 \\
\hline \multicolumn{2}{|l|}{ D10 } & 413,000円以上 & 57,100 & 28,550 & 28,500 & 14,250 & 27,800 & 13,900 \\
\hline \multicolumn{9}{|c|}{ 網掛け部分は、せんだい保育室の保育料と同程度(差が-1,000円以内)、又はそれ以上の金額である事を示す。 } \\
\hline & & & \multicolumn{6}{|c|}{ せんだい保育室 (各施設ごとに設定,月額) } \\
\hline \multicolumn{3}{|c|}{ 全階層 } & 53,600 & 26,800 & 27,600 & 13,800 & 26,800 & 13,400 \\
\hline
\end{tabular}

表 7 せんだい保育室連絡会の活動による改善項目

\begin{tabular}{|c|c|}
\hline 実施年 & 改善された項目 \\
\hline $\begin{array}{l}2003 \\
-2004\end{array}$ & 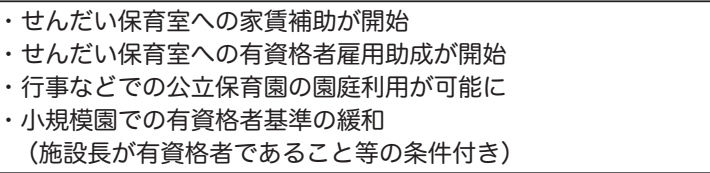 \\
\hline 2005 & $\begin{array}{l}\text { •市政だよりに認可保育所と共にせんだい保育室の情報が掲載 } \\
\text { • 連絡会のPR として公共施設へのチラシ配付が許可 }\end{array}$ \\
\hline 2006 & - 園児の健康診断費への助成 \\
\hline 2007 & $\begin{array}{l}\text { • 保育料の多子減免制度の実施 } \\
\text { (兄弟姉妹が幼稚園・認可保育所・せんだい保育室に通う場合、 } \\
\text { 第二子の保育料を半額、第三子の保育料を無料に) }\end{array}$ \\
\hline 2010 & $\begin{array}{l}\text { •保育料の保護者負担軽減制度の実施 } \\
\text { ( } 3 \text { 歳未満児の保護者の所得が一定以下の場合、保育料を減額) }\end{array}$ \\
\hline
\end{tabular}

的に分離した事例だけでなく、上下階に跨って立体的に分離した事 例も見られた。こうした事例では、職員間の連携や配膳時などの点 で運営上の工夫が必要となっていたが、0-2 歳児 3-5 歳児とは独立 させた方が園児が落ち着いて生活できるとの意見も聞かれた。

4) 自己所有建物を利用した事例では、主に自宅を利用して増改築 が行われていた。「敷地内の増築余地の有無」「隣接地の活用の有無」 で分類すると、(1)既存建物の改修のみのケース、(2)敷地内での既存 建物への増改築が行われたケース、(3)隣接地の空家を含めた一体的 な増改築が行われたケース、の3タイプに大きく分けられた。今回 の調查事例では増築規模も小規模で対象時期も異なるため該当しな かったが、近年の建築基準法改正に伴い、増築面積の規模次第では 既存建物への遡及適用が問題となることも想定され、今後は遡及適 用の可能性についても検討が必要になると考えられる。

5 ) 所得に応じて保護者の負担額が決まる認可保育所とは異なり、 せんだい保育室では基本的に児童の年齢によって保護者の負担額が 
決定される。従って、所得が高く認可保育所の保育料と大差ない利 用者は自ら選択してせんだい保育室を利用しているケースも見られ るが、所得が低い利用者は保育料の安い認可保育所に空きが出ると 移ってしまう等の問題点も指摘された。こうした認可保育所との落 差を改善するためにせんだい保育室連絡会では継続的な活動が行わ れており、有資格者雇用助成や保育料の多子減免制度、所得に伴う 保育料の保護者負担軽減等がこれまでに実現されている。

認可外保育施設を含めた保育所全体の水準向上に向けて、今後は、 自治体単独保育室を導入している他の自治体の調查に加えて、2013 年開始予定の子ども・子育て新システムへの移行が自治体単独保育 室に及ぼす影響についても引き続き調査を行っていく必要があると 思われる。

\section{謝辞}

本研究を行う上で、せんだい保育室各園、せんだい保育室連絡協 議会、仙台市子供未来局保育指導課の皆様にはヒアリング調査や資 料収集に多大なる御協力を頂きました。末筆ながら感謝の意を表し ます。また当時修論生で調査結果の整理等に尽力してくれた佐藤千 草君にも感謝します。尚、本研究の一部は平成 22 年度第一住宅建設 協会並びに 2011 年度日揮・実吉奨学会の研究助成によるものである。

\section{注}

注 1 ）認可保育所最低基準の歩みについては文献 4 が詳しい。

注 2 )「自治体単独保育室」については、2009 年 6 月の社会保障審議会児童部 会資料 (http://www.mhlw.go.jp/shingi/2009/06/s0608-11.html) の中でも、 「認可外保育施設の中には、自治体独自の基準による補助を受けている施設」 は「東京都認証保育所や横浜保育室等のいわゆる『自治体単独保育室』」

して表記されている。

注 3 ) 文献 5 による。

注 4) 文献 6 ・7 による。

注 5）文献8による。

注 6 ) 文献 $9 \cdot 10$ による。

注 7 ）文献 11 による。

注 8）文献 12 による。

注 9）グラフの作成に際して、自治体単独保育室数、認可保育所数のデータは 2011 年 4 月時点のものである。また認可外保育施設数についてはべビーホ テルを除いており、2010 年 3 月時点のものである。待機児童数については 2010 年 4 月時点のデータを用いている。

注 10）各自治体の商業地・住宅地の地点数はそれぞれ、仙台市が 73 力所・ 233 力所、東京都が 683 力所・826 力所、横浜市が 156 力所・559 力所、 浜松市が 29 力所・60 力所、堺市が 13 力所・140 力所であった。

注 11）家庭保育室は、仙台市において「乳児及び幼児を保育する施設として 必要な一定の基準に適合するものとして市長の指定をうけた」認可外保育施 設のことであり、1973 年〜 2002 年まで運営者への助成が行われていた。 具体的な基準の内容は表 2 を参照。

注 12）せんだい保育室連絡会へのヒアリングによると、せんだい保育室への制 度変更に向けた説明会等の場では保育室面積の引上げがもたらす利点につい て行政側からの説明は殆ど無く、保育環境の水準向上といった視点よりも、 むしろ運営費助成単価を引き上げる代わりに、有資格者の割合と保育室の面 積基準、2 点の引上げが提示された印象が強い、との事であった。尚、家庭 保育室からせんだい保育室への移行時の問題については文献 13 でも言及さ れている。

注 13）せんだい保育室連絡会会長（家庭保育室からせんだい保育室へ移行し た園の園長）へのヒアリングでは、B 型については施設拡張に伴う改修費用
について自治体からの助成は無かったとのことである。また A 型については 施設開設時のみ、費用の $3 / 4 、 1500$ 万を上限とした施設整備助成が設けら れている。

注 14）文献 11 による。

注 15）厚生労働省の発表では、2010 年 4 月時点の全国の待機児童数 26,275 人の内、3歳未満児は 21,537 人 $(82 \%) 、 2010$ 年 10 月時点では全国の待機 児童数 48,356 人の内、 3 歳未満児は 42,410 人 $(88 \%)$ となっている。

注 16）住宅系の用途地域を「住宅地」、商業系の用途地域を「商業地」、その 他の場合を「その他」としている。

注 17）AS 園では保育室の面積に余裕があったため増床は行われていないが、 保育室が 5 階に設けられているため、耐火構造の避難階段の設置や内装の不 燃材化が必要となるなど、中高層建築物ならではの改善が必要であった。

注 18）本文中にも記載しているように、今回の調査事例では、保育室の面積 を単純に増加させただけではなく、定員を大幅に増加させた園、上下階や隣 接建物一保育室が分かれた園、低年齢児と高年齢児とを分離させた園など、 従前と状況が大幅に変化している園が殆どである。したがって、保育室面積 の量的な増加が及ぼした影響については当然あったと思われるが、今回の事 例からその影響のみを考察するのは難しいと思われる。

注 19） CB 園は定員が 20 名と少ない事もあり、小学校への移行時の影響を考 慮して対象児童が $0 〜 2$ 歳児に限定されている。

注 20）園へのヒアリングでは、定員の少ない小規模な園では園児数の変動が 園の経営により大きな影響を与えるとの事で、小規模な園では定員をできる 限り増やしたいとの意向を持っているようである。

注 21）せんだい保育室連絡会には、全ての園が参加している訳ではないが、B 型の園を中心に約 6 割の園が参加しているとのことである。

注 22） 2010 年 4 月より実施された保育料の保護者負担軽減制度では、前年分 の世帯所得税額合計が 72,000 円未満（表 6 の D6 以下の階層区分）の場合、 3 歳未満の第 1 子・第 2 子を対象に、第 1 子については 15,000 円、第 2 子 については 7,500 円の保育料負担が軽減されることとなった。仙台市保育課 の資料によると、2010 年 4 月時点でせんだい保育室を利用する 3 歳未満児 の約 1/3 が D6 以下の階層区分の世帯とのことである。

\section{参考文献}

1）鈴木健二, 佐藤千草：仙台市における助成保育施設の現状と課題に関する 研究 1, 日本建築学会大会学術講演梗概集, E-1, pp.587-588, 2010

2）佐藤千草, 鈴木健二 : 仙台市における助成保育施設の現状と課題に関する 研究 2, 日本建築学会大会学術講演梗概集, E-1, pp.589-590, 2010

3）鈴木健二：せんだい保育室に打ける戸建住宅から保育施設への転用に関す る研究, 日本建築学会大会学術講演梗概集, E-1, pp.139-140, 2011

4）村山祐一：もっと考えて!!子どもの保育条件 保育所最低基準の歩みと 課題, 新読書社, 2001

5) 山田他：幼保一体型施設における運営様態, 混合保育, 活動場所の変遷に 関する研究，日本建築学会計画系論文集，No.625, pp.543-550, 2008.3

6 ）小池他：都市部に拀ける保育施設の屋外保育環境について, 日本建築学会計画系論文集，No.628，pp.1197-1204， 2008.6

7 ）松橋他：保育施設に扔ける屋外環境と園外活動の実態からみた地域資源のあ り方に関する研究，日本建築学会計画系論文集，No.651, pp.1017-1024, 2010.5

$8 ）$ 細谷他：異年齢保育における保育室の空間構成と室内遊びでの異年齢交流 の実態の研究, 日本建築学会計画系論文集, No.634, pp.2565-2572, 2008.12

9）近藤他：保育所における幼児の食寝空間からみた面積基準のあり方につい て, 日本建築学会計画系論文集, No.645, pp.2371-2377, 2009.11

10）近藤他：保育所における 0 歳児の食事・午睡・あそびの行為と面積につい て, 日本建築学会計画系論文集, No.653, pp.1647-1654, 2010.7

11）小池他：東京都区部に打ける複合型保育所の施設環境に関する研究, 日本建築学会計画系論文集，No.628, pp.47-53，2008.6

12）鈴木亘：財政危機と社会保障，講談社現代新書，2010.9

13）小野枝美子：家庭保育室から「せんだい保育室」への移行と問題点 季刊保育問題研究, 199 号, pp.247-251, 2003.3

14）せんだい保育室連絡会ホームページ（http://www.e-hoiku.jp/) 2011.09.13 参照 